\title{
Carotenoid Production by Rhodotorula mucilaginosa in Batch and Fed-Batch Fermentation Using Agroindustrial Byproducts
}

\author{
Tábita Veiga Dias Rodrigues*๑), \\ Thalita D. Amoreø, \\ Erika Carvalho Teixeira๑ and \\ Janaina Fernandes de \\ Medeiros Burkert॰
}

School of Chemistry and Food, Federal University of Rio Grande, 96203-900 Rio Grande, Brazil

Received: 3 October 2018 Accepted: 17 June 2019

\section{(i) ()}

*Corresponding author:

Phone: +555332336542

E-mail: tata.v.d.r@hotmail.com

\section{SUMMARY}

Carotenoids are natural pigments that can be produced through biotechnological processes. However, the costs are relatively high and can be minimized by using lower-cost substrates as alternative nutrient sources. The fed-batch fermentation is one of the techniques used to obtain a high biomass concentration and/or maximum production. Thus, the aim of this work is to produce carotenoids in batch and fed-batch fermentation with the yeast Rhodotorula mucilaginosa CCT 7688 using agroindustrial byproducts in the culture medium. Carotenoid production was increased using experimental designs, which modified the concentration of the agroindustrial medium. In batch production the highest concentrations of total carotenoids $(1248.5 \mu \mathrm{g} / \mathrm{L})$ and biomass $(7.9 \mathrm{~g} / \mathrm{L})$ were obtained in the medium containing $70 \mathrm{~g} / \mathrm{L}$ sugar cane molasses and $3.4 \mathrm{~g} / \mathrm{L}$ corn steep liquor at $25^{\circ} \mathrm{C}$ and $180 \mathrm{rpm}$ in $168 \mathrm{~h}$, demonstrating an increase of $17 \%$ when compared to the standard yeast malt medium $(1200 \mu \mathrm{g} / \mathrm{L})$. In the fed-batch production, different feeding strategies were tested with $30 \mathrm{~g} / \mathrm{L}$ sugar cane molasses and $6.5 \mathrm{~g} / \mathrm{L}$ corn steep liquor, reaching a total carotenoid production of $3726 \mu \mathrm{g} / \mathrm{L}$ and biomass concentration of $16 \mathrm{~g} / \mathrm{L}$. Therefore, the strategy of the fed-batch process resulted in an increase in the carotenoid production of approx. $400 \%$ compared to that in the batch process $(740.3 \mu \mathrm{g} / \mathrm{L})$. Thus, the R. mucilaginosa strain has the potential to produce carotenoids in agroindustrial medium.

Key words: $\beta$-carotene, feeding strategies, corn steep liquor, sugar cane molasses, yeast

\section{INTRODUCTION}

Carotenoids are natural pigments found abundantly in nature whose isolation and characterization have identified more than 600 molecules, allowing a great applicability of these compounds, resulting in an increase in their use in the food, cosmetics and pharmaceutical industries (1). These compounds are responsible for the intense colouring of fruits, vegetables, flowers, algae, bacteria and fungi (2), which varies from yellow to red, and are the most studied natural pigments (3). The carotenoid world market in 2017 was US\$ 1.5 billion with a forecast of US\$ 2.0 billion for 2022. $\beta$-Carotene is the most commonly consumed carotenoid, with a market worth of US\$261 million in 2010 and an estimation of US\$ 334 million in 2018 (4).

The carotenoids, which are marketed as food additives and supplements, are mainly obtained by synthetic methods (3). However, their production by natural processes has increased due to the market demand for healthier foods with health benefits, in addition to the concern of the consumers for the use of chemical additives in food (5). The antioxidant capacity (6), the provitamin A activity, and the reduction of the risk of developing degenerative (7) and cardiovascular diseases (8) are some of the beneficial health effects provided by carotenoids.

These compounds obtained in bioprocesses can be produced by a diversity of microorganisms, such as microalgae (9-11) bacteria (12-14), fungi (15-16) and yeasts (17-19). However, the production of carotenoids using biotechnological processes still has a high cost. Therefore, an alternative to minimize the cost of this process is the utilization of agroindustrial byproducts as sources of alternative nutrients (20). The genus Rhodotorula has been studied with the use of low-cost substrates, such as sugar cane molasses (21), raw glycerol (22) and coffee grounds 
(23), to produce carotenoids. Although several microorganisms can biosynthesize carotenoids, not all of them are of interest for industry. However, yeasts need a source of carbon and nitrogen for biosynthesis, which is relatively simple when compared to other microorganisms (24).

The yeast Rhodotorula mucilaginosa utilized in this study was isolated previously (25) and it demonstrated the ability to produce carotenoids in media containing agroindustrial byproducts, such as rice parboiling wastewater, raw glycerol, sugar cane molasses and corn steep liquor (26), with antioxidant activity. Another factor that may increase the production of carotenoids is the use of the fed-batch fermentation. This process controls the substrate concentration, timing its addition at moments indicated as favourable, minimizing the effects of inhibition of the microorganism by the substrate and possibly improving the production of the biocompound $(27,28)$.

Few studies are found in the literature that evaluate the carotenoid production using agroindustrial byproducts as potential sources of nutrients in fed-batch process using the yeast Rhodotorula mucilaginosa. In this work we aim to maximize the carotenoid production by Rhodotorula mucilaginosa in shake flasks with the use of agroindustrial byproducts and study different strategies of feeding in a fed-batch process.

\section{MATERIALS AND METHODS}

\section{Microorganism}

The yeast Rhodotorula mucilaginosa CCT 7688 used in this study was previously isolated (25) from environmental samples obtained in the region of Escudo Sul-Rio Grandense, Rio Grande do Sul (Brazil), identified and deposited at the André Tosello Tropical Culture Collection.

\section{Agroindustrial byproducts}

The agroindustrial byproducts used in this study were corn steep liquor from Corn Products (Paraná, Brazil), sugar cane molasses obtained from Melaços Brasileiros (São Paulo, Brazil) and raw glycerol from the synthesis of biodiesel from BS Bios Indústria e Comércio de Biodiesel Sul Brasil S/A (Rio Grande do Sul, Brazil). A partial characterization of raw glycerol and substrates for yeast malt (YM) medium was performed, and the mass fractions of carbon and nitrogen were determined using a CHNS/O analyzer (Perkin Elmer 2400, Rodgau, Germany). Carbon in the sugar cane molasses was determined with the total organic carbon and total nitrogen analyzer (TOC-VCSH model; Shimadzu, Tokyo, Japan), and corn steep liquor was previously characterized (26).

\section{Maintenance and reactivation of microorganisms}

The microorganisms were maintained in YM agar slant tubes with (in $\mathrm{g} / \mathrm{L}$ ): yeast extract 3, malt extract 3, peptone 5 , agar 20 (all from KASVI, São José do Pinhais, PR, Brazil), glucose 10 (Synth, São Paulo, Brazil) and $\mathrm{KNO}_{3} 0.2$ (Synth) at $4{ }^{\circ} \mathrm{C}$ (29) for 3 months. For reactivation, the microorganisms were transferred to the same medium and incubated at $25^{\circ} \mathrm{C}$ for 48 h. From the tubes containing the microorganisms in YM agar slants, $1 \mathrm{~mL}$ of cell suspension in $0.1 \%$ sterile peptone water were added to $9 \mathrm{~mL}$ of YM broth and incubated before inoculation under the same conditions described previously (29).

\section{Carotenoid production in shake flasks}

The inoculum was prepared in 250-mL Erlenmeyer flasks with $90 \mathrm{~mL}$ YM broth (29) and $10 \mathrm{~mL}$ previously grown culture and incubated (incubator model TE-420; Tecnal, Piracicaba, Brazil) at $25^{\circ} \mathrm{C}$ and $150 \mathrm{rpm}$ for $48 \mathrm{~h}$ or for the time needed to reach $10^{8}$ cells $/ \mathrm{mL}$, counted using a Neubauer chamber (Laboroptik, Lancing, UK) (30). Carotenoid bioproduction in batch and fed-batch processes was conducted in 500-mL Erlenmeyer flasks with $225 \mathrm{~mL}$ agroindustrial culture medium at an initial $\mathrm{pH}=6.0$ and $10 \%$ inoculum (cultivation started with $10^{7}$ cells $/ \mathrm{mL}$ ). The conditions of the process were $25^{\circ} \mathrm{C}, 180 \mathrm{rpm}$ for up to $216 \mathrm{~h}$ (31). Culture samples were collected every $24 \mathrm{~h}$ to determine the $\mathrm{pH}$, biomass concentration, total reducing sugars and production of carotenoids.

\section{Selection of agroindustrial medium for the production of carotenoids}

Preliminary experiments were conducted to select the agroindustrial medium. Two formulations of agroindustrial byproducts were studied for the carotenoid production: corn steep liquor $(35.6 \mathrm{~g} / \mathrm{L})$ with raw glycerol $(6.6 \mathrm{~g} / \mathrm{L})$ and corn steep liquor (36.5 g/L) with sugar cane molasses $(6 \mathrm{~g} / \mathrm{L}$ ) according to Cipolatti (26), and compared with YM medium (Table 1).

\section{Experimental design for batch carotenoid production}

To maximize the batch carotenoid production, a study of the composition of the agroindustrial medium formulated with corn steep liquor and sugar cane molasses was conducted using two central composite designs (Table 2). The evaluated responses were the maximum volumetric concentration of carotenoids ( $\mu \mathrm{g} / \mathrm{L}$ ) throughout the process, the specific mass fraction of carotenoids $(\mu \mathrm{g} / \mathrm{g}$ ) and biomass concentration $(\mathrm{g} / \mathrm{L})$, all determined at the same time. The experiments were performed in triplicate, under the incubation conditions described previously to validate the maximum carotenoid production using agroindustrial substrates.

\section{Fed-batch fermentation}

Based on the results of the batch fermentation, two production media were defined to evaluate fed-batch process: the first contained $3.5 \mathrm{~g} / \mathrm{L}$ corn steep liquor and $70 \mathrm{~g} / \mathrm{L}$ sugar cane molasses with one-pulse feeding in $168 \mathrm{~h}$. The second culture medium contained $6.5 \mathrm{~g} / \mathrm{L}$ corn steep liquor and $30 \mathrm{~g} / \mathrm{L}$ sugar cane molasses with different feeding pulses (using the same amount of each component in the pulse): run 1 (one pulse at 96 h), run 2 (one pulse at 48 h), run 3 (one pulse at 72 h), run 4 
Table 1. Partial characterization of substrates, C:N ratio, carotenoid production by Rhodotorula mucilaginosa and productivity in different culture media at $25^{\circ} \mathrm{C}$, initial $\mathrm{pH}=6.0$ and $180 \mathrm{rpm}$

\begin{tabular}{|c|c|c|c|c|c|c|c|c|c|c|}
\hline \multirow{2}{*}{ Substrate } & \multicolumn{3}{|c|}{$w / \%$} & \multirow{2}{*}{$\gamma($ medium $) /(\mathrm{g} / \mathrm{L})$} & \multirow{2}{*}{$\mathrm{C}: \mathrm{N}$ ratio } & \multirow[b]{2}{*}{$w_{\mathrm{SC}} /(\mu \mathrm{g} / \mathrm{g})$} & \multirow[b]{2}{*}{$\gamma_{\mathrm{vc}} /(\mu \mathrm{g} / \mathrm{L})$} & \multirow[b]{2}{*}{$\gamma$ (biomass)/(g/L) } & \multirow[b]{2}{*}{$r_{\mathrm{b}} /(\mathrm{g} /(\mathrm{L} \cdot \mathrm{h}))$} & \multirow[b]{2}{*}{$r_{\mathrm{vc}} /(\mu \mathrm{g} /(\mathrm{L} \cdot \mathrm{h}))$} \\
\hline & C & $\mathrm{N}$ & $\mathrm{H}$ & & & & & & & \\
\hline $\mathrm{CSL}^{*}$ & 17.83 & 3.80 & 2.41 & CSL $36.5+$ SCM 6.0 & 6.04 & $(96.4 \pm 9.8)^{a}$ & $(336 \pm 10)^{a}$ & $(4.5 \pm 1.1)^{\mathrm{a}}$ & $(0.10 \pm 0.01)^{\mathrm{a}}$ & $(14.0 \pm 0.4)^{\mathrm{a}}$ \\
\hline SCM & 31.47 & 0.04 & - & & & & & & & \\
\hline RG & 31.50 & $<0.07$ & 2.27 & CSL 35.6 +RG 6.6 & 6.20 & $(78.7 \pm 7.2)^{a}$ & $(297 \pm 15)^{b}$ & $(4.2 \pm 0.4)^{b}$ & $(0.07 \pm 0.00)^{\mathrm{b}}$ & $(6.2 \pm 0.7)^{\mathrm{b}}$ \\
\hline Yeast extract & 41.26 & 11.45 & 5.35 & & & & & & & \\
\hline Malt extract & 42.11 & 1.41 & 5.42 & YM & 8.28 & $176.3 \pm 4.5$ & $1200 \pm 75$ & $7.1 \pm 0.3$ & $0.080 \pm 0.004$ & $15.1 \pm 2.1$ \\
\hline Peptone & 12.16 & 2.70 & 1.46 & & & & & & & \\
\hline
\end{tabular}

$\mathrm{CSL}=$ corn steep liquor, $\mathrm{SCM}=$ sugar cane molasses, $\mathrm{RG}=$ raw glycerol, $\mathrm{YM}=$ yeast malt medium; ${ }^{*}$ composition according to $C$ ipolatti $(26) ; w_{\mathrm{SC}}=$ specific carotenoid mass fraction, $\gamma_{\mathrm{vc}}=$ volumetric carotenoid concentration, $r_{\mathrm{b}}=$ biomass productivity and $r_{\mathrm{vc}}=$ volumetric carotenoid productivity, expressed as mean value \pm standard deviation $(N=3)$; different letters in the same column indicate a significant difference ( $p<0.05$ ) according to Student's $t$-test

Table 2. Coded levels and real values (in parentheses) of the first and second central composite design (CCD $2^{2}$ ) used for batch carotenoid production on agroindustrial media

\begin{tabular}{|c|c|c|c|c|c|c|c|c|c|c|c|}
\hline \multicolumn{12}{|c|}{ First central composite design } \\
\hline Assay & $\mathrm{X}_{1}$ & \multicolumn{2}{|c|}{$\mathrm{X}_{2}$} & $\mathrm{R}_{1}$ & \multicolumn{2}{|c|}{$\mathrm{R}_{2}$} & $t_{c} / \mathrm{h}$ & $\mathrm{R}_{3}$ & \multicolumn{2}{|c|}{$\mathrm{R}_{4}$} & $\mathrm{R}_{5}$ \\
\hline 1 & $-1(10)$ & \multicolumn{2}{|c|}{$-1(3.5)$} & 2.6 & \multicolumn{2}{|c|}{479} & 168 & 177.9 & \multicolumn{2}{|c|}{0.0} & 27.5 \\
\hline 2 & $+1(50)$ & \multicolumn{2}{|c|}{$-1(3.5)$} & 8.7 & \multicolumn{2}{|c|}{1040} & 144 & 119.2 & \multicolumn{2}{|c|}{5.1} & 106.9 \\
\hline 3 & $-1(10)$ & \multicolumn{2}{|c|}{$+1(9.5)$} & 3.1 & \multicolumn{2}{|c|}{407} & 120 & 128.0 & \multicolumn{2}{|c|}{0.0} & 13.2 \\
\hline 4 & $+1(50)$ & \multicolumn{2}{|c|}{$+1(9.5)$} & 7.2 & \multicolumn{2}{|c|}{1077} & 168 & 149.3 & \multicolumn{2}{|c|}{3.5} & 45.7 \\
\hline 5 & $0(30)$ & \multicolumn{2}{|c|}{$0(6.5)$} & 7.2 & \multicolumn{2}{|c|}{80} & 144 & 110.8 & \multicolumn{2}{|c|}{1.6} & 42.0 \\
\hline 6 & $0(30)$ & \multicolumn{2}{|c|}{$0(6.5)$} & 5.8 & \multicolumn{2}{|c|}{74} & 168 & 127.3 & \multicolumn{2}{|c|}{1.3} & 42.0 \\
\hline 7 & $0(30)$ & \multicolumn{2}{|c|}{$0(6.5)$} & 5.1 & \multicolumn{2}{|c|}{670} & 144 & 130.4 & \multicolumn{2}{|c|}{1.76} & 42.0 \\
\hline \multicolumn{12}{|c|}{ Second central composite design } \\
\hline Assay & $\mathrm{X}_{1}$ & $\mathrm{X}_{2}$ & $\mathrm{R}_{1}$ & $\mathrm{DR}_{1}$ & $\mathrm{R}_{2}$ & $t_{c} / \mathrm{h}$ & $\mathrm{DR}_{2}$ & $\mathrm{R}_{3}$ & $\mathrm{DR}_{3}$ & $\mathrm{R}_{4}$ & $\mathrm{R}_{5}$ \\
\hline 1 & $-1(50)$ & $-1(0.58)$ & 4.88 & 8.20 & 623 & 168 & 9.31 & 127.71 & 7.17 & 4.86 & 370.14 \\
\hline 2 & $+1(70)$ & $-1(0.58)$ & 6.74 & 0.89 & 909 & 144 & 8.14 & 134.98 & 1.57 & 15.66 & 435.75 \\
\hline 3 & $-1(50)$ & $+1(3.41)$ & 7.17 & 0.98 & 1077 & 168 & 6.87 & 163.62 & 6.50 & 3.14 & 109.26 \\
\hline 4 & $+1(70)$ & $+1(3.41)$ & 8.10 & 4.94 & 1404 & 168 & 3.49 & 173.39 & 0.35 & 12.69 & 143.65 \\
\hline 5 & $0(60)$ & $0(2)$ & 7.28 & 5.36 & 1209 & 168 & 11.75 & 166.15 & 6.72 & 4.57 & 192.39 \\
\hline 6 & $0(60)$ & $0(2)$ & 7.07 & 2.55 & 1104 & 168 & 3.35 & 156.22 & 0.74 & 3.67 & 192.39 \\
\hline 7 & $0(60)$ & $0(2)$ & 6.98 & 1.29 & 1141 & 168 & 6.49 & 165.61 & 6.15 & 3.55 & 192.39 \\
\hline
\end{tabular}

$\mathrm{X}_{1}=\gamma(\mathrm{SCM}) / \mathrm{g} / \mathrm{L}, \mathrm{X}_{2}=\gamma(\mathrm{CSL}) /(\mathrm{g} / \mathrm{L}), \mathrm{R}_{1}=\gamma$ (biomass)/(g/L), $\mathrm{R}_{2}=\gamma \mathrm{VC} /(\mu \mathrm{g} / \mathrm{L}), \mathrm{R}_{3}=w S C /(\mu \mathrm{g} / \mathrm{g}), \mathrm{R}_{4}=\gamma$ (total reducing sugar)/(g/L) and $\mathrm{R}_{5}=\mathrm{C}: \mathrm{N}$ ratio (for abbreviations see legend of Table 1); $\mathrm{DR}_{1}=$ relative deviation of biomass concentration, $\mathrm{DR}_{2}=$ relative deviation of volumetric carotenoid concentration and $\mathrm{DR}_{3}=$ relative deviation of specific carotenoids; $t_{c}=$ time of cultivation needed for maximum volumetric production of carotenoids

(one pulse at 48 and one at $96 \mathrm{~h}$ ), run 5 (one pulse at 72 and one at $120 \mathrm{~h}$ ), run 6 (one pulse at 96 and one at $144 \mathrm{~h}$ ) and run 7 (one pulse at 96 and one at $168 \mathrm{~h}$ ). The feeding strategies for the fed-batch process were based on the procedure described by Chang et al. (32).

\section{Extraction and determination of total carotenoids}

The biomass was recovered using centrifugation (Cientec CT-5000R; Belo Horizonte, Brazil) at $3439 \times \mathrm{g}$ for $10 \mathrm{~min}$ and dried for $48 \mathrm{~h}$ at $35{ }^{\circ} \mathrm{C}$ to extract the carotenoids (33). It was subsequently macerated with a mortar and pestle and standardized with 115 mesh (26). The samples were frozen for $48 \mathrm{~h}$ at $-18^{\circ} \mathrm{C}$ (33). The cells were disrupted with dimethylsulfoxide (DMSO; Synth) as described by Michelon et al. (30). In tubes containing $0.05 \mathrm{~g}$ of biomass, $2 \mathrm{~mL}$ of DMSO were added at $55^{\circ} \mathrm{C}$ and homogenized for $1 \mathrm{~min}$ in a vortex (Biomixer QL901, Ningbo, PR China) at 15 min intervals for a total of $1 \mathrm{~h}$.
After cell disruption, $6 \mathrm{~mL}$ of acetone (Neon, Suzano, SP, Brazil) were added to stimulate the extraction and the suspension was centrifuged at $1745 \times g$ (CT-5000R; Cientec) for $10 \mathrm{~min}$. The supernatant was separated, and the procedure was repeated until the cells were totally bleached. A volume of $10 \mathrm{~mL}$ of 20 $\% \mathrm{NaCl}$ solution ( $\mathrm{m} / \mathrm{V}$ ) (Synth) and $10 \mathrm{~mL}$ of petroleum ether (Neon) were added to the supernatants. After the formation of two phases, the apolar phase was filtered with $\mathrm{Na}_{2} \mathrm{SO}_{4}$ (Neon) to form the carotenogenic extracts (30).

The total carotenoid mass fraction in the extracts was determined at $448 \mathrm{~nm}$ using spectrophotometer model SP-220 (Biospectro, Zhejiang, PR China) and expressed as its major component ( $\beta$-carotene in petroleum ether with a specific absorbance of $A_{1 \mathrm{~cm}}^{1 \%}=2592$ using the following equation (34):

$$
W_{\mathrm{TC}}=\left(A \cdot V \cdot 10^{6}\right) /\left(A_{1 \mathrm{~cm}}^{1 \%} \cdot 100 \cdot m_{\text {sample }}\right)
$$

where $w_{\mathrm{TC}}$ is the mass fraction total of carotenoids $(\mu \mathrm{g} / \mathrm{g}), A$ is the absorbance, $V$ is the volume of carotenoids $(\mathrm{mL}), m_{\text {sample }}$ 
is the dried cell mass $(\mathrm{g})$, and $A_{1 \mathrm{~cm}}^{1 \%}$ is the specific absorbance. The volumetric concentration of carotenoids $(\mu \mathrm{g} / \mathrm{L})$ was calculated using the mass fraction of total carotenoids $(\mu \mathrm{g} / \mathrm{g})$ multiplied by the biomass concentration ( $\mathrm{g} / \mathrm{L})$.

\section{Determination of $\mathrm{pH}$ and biomass concentration}

Aliquots were taken from the fermentation and centrifuged (1745 $\times g$ for $10 \mathrm{~min}$ ), the supernatants were separated for $\mathrm{pH}$ determination with a potentiometer (Quimis Q400MT; São Paulo, Brazil) as described by the AOAC official method 972.44 (35). The biomass concentration throughout the process was estimated by measuring the absorbance at $620 \mathrm{~nm}$ (SP-220; Biospectro) using a previously constructed standard biomass curve ( $\mathrm{g} / \mathrm{L})(36)$.

\section{Determination of total reducing sugars}

Total reducing sugars were determined spectrophotometrically at $540 \mathrm{~nm}$ (SP-220; Biospectro) with 3,5-dinitrosalicylic acid (DNS; Vetec, São Paulo, Brazil) as described by Miller (37) using a standard glucose curve. The sugar determination was performed in the culture medium previously centrifuged (CT $5000 \mathrm{R}$; Cientec) at $3439 \times \mathrm{g}$ for $10 \mathrm{~min}$. The agroindustrial medium containing sugar cane molasses was previously subjected to hydrolysis with $2 \mathrm{~mL}$ of $2 \mathrm{~mol} / \mathrm{L} \mathrm{HCl}$ (Neon) in boiling water $\left(100^{\circ} \mathrm{C}\right.$ for $\left.10 \mathrm{~min}\right)$, followed by the addition of $2 \mathrm{~mL}$ of $2 \mathrm{~mol} / \mathrm{L} \mathrm{NaOH}$ (Neon) to neutralize the acid (38).

\section{Determination of the kinetic parameters}

The volumetric carotenoid productivity, $r_{\mathrm{vc}}(\mu \mathrm{g} /(\mathrm{L} \cdot \mathrm{h}))$, and biomass productivity, $r_{b}(g /(L \cdot h))$, were calculated using the following equations:

$$
r_{\mathrm{vc}}=\left(\gamma_{\max }-\gamma_{0}\right) / t_{\mathrm{f}}
$$

and

$$
r_{\mathrm{b}}=\left(\mathrm{X}_{\max }-\mathrm{X}_{0}\right) / t_{\mathrm{f}}
$$

where $\gamma_{\max }$ and $\gamma_{0}$ are the maximum and initial volumetric concentrations of carotenoids $(\mu \mathrm{g} / \mathrm{L})$ respectively, $t_{\mathrm{f}}$ is fermentation time (h) at which the maximum volumetric concentration of carotenoids was obtained, $\mathrm{X}_{\max }$ is biomass concentration $(\mathrm{g} / \mathrm{L})$ at $t_{\mathrm{f}}$, and $\mathrm{X}_{0}$ is initial biomass concentration $(\mathrm{g} / \mathrm{L})$.

\section{Statistical analysis}

Data were analysed using Statistica software v. 5.0 (18). All analyses used a $95 \%$ confidence level $(p<0.05)$. An analysis of variance (ANOVA) was used to estimate the statistical parameters. The mean value was compared by Tukey's test at a $5 \%$ significance level. For the comparison between two treatments, the Student's $t$-test $(p<0.05)$ was used. Contour surfaces were drawn as described by Box et al. (39) and Rodrigues and lemma (40).

\section{RESULTS AND DISCUSSION}

\section{Characterization of substrates of the culture medium and influence on the carotenoid production}

The partial characterization, including carbon and nitrogen mass fractions, of the substrates used in the formulations of the culture medium to produce carotenoids (Table 1 ) is consistent with the literature findings for these agroindustrial residues $(25,26,41)$. The production of various biomolecules, such as lipids, rhamnolipids (42), exopolysaccharides (43) and carotenoids (44), can be influenced by the C:N ratio. The YM, corn steep liquor with raw glycerol and corn steep liquor with sugar cane molasses had a C:N ratio of 8.28, 6.20 and 6.04, respectively (Table 1). A C:N ratio higher than 5.0 may positively influence carotenoid production as described for Phaffia rhodozyma $(17,31,44)$. Therefore, agroindustrial media with this $\mathrm{C}: \mathrm{N}$ ratio are promising sources of alternative substrates for carotene bioproduction.

The highest specific mass fraction and volumetric concentration of carotenoids, as well as volumetric carotenoid productivity, were in the YM medium (Table 1), having a C:N ratio higher than that of the two agroindustrial media tested, which may have influenced the production of the carotenoids and biomass. However, carotenoid synthesis was similar in both agroindustrial media, with a C:N ratio close to 6.0 (Table 1), since there was no significant difference ( $p>0.05$ ) in the specific carotenoid production. The corn steep liquor with sugar cane molasses was selected to maximize the carotenoid production because it resulted in a volumetric concentration, biomass concentration, biomass productivity and volumetric productivity higher by 12.0, $6.7,55.7$ and $30.0 \%$, respectively, than of the corn steep liquor with raw glycerol.

\section{Maximization of carotenoid production}

The use of an experimental design enables the study of the influence of the levels of one factor on the response variable. Thus, the primary effects of such a design may be simply calculated as the difference between the average value of the measurements made at the high level $(+1)$ of the variable and the average value of measurements at the low level (-1) (40). The first experimental design was conducted using a central composite design (CCD) to evaluate the primary effects of the concentrations of sugar cane molasses and corn steep liquor in the medium on the production of carotenoids. The real and coded values of the investigated variables with the respective responses are shown in Table 2.

In the first central composite design the volumetric concentration of carotenoids ranged from $407 \mu \mathrm{g} / \mathrm{L}$ (assay 3 ) to $1077 \mu \mathrm{g} / \mathrm{L}$ (assay 4), the specific carotenoid mass fraction from $110.8 \mu \mathrm{g} / \mathrm{g}$ (assay 5) to $177.9 \mu \mathrm{g} / \mathrm{g}$ (assay 1), biomass concentration from $2.6 \mathrm{~g} / \mathrm{L}$ (assay 1 ) to $8.7 \mathrm{~g} / \mathrm{L}$ (assay 2), and the C:N ratio of the production medium from 13.2 (assay 3 ) to 106.9 (assay 2). The final concentration of the total reducing sugars in assays 1 and 3 was not detected, indicating the total sugar consumption by the yeast, while it was $5.1 \mathrm{~g} / \mathrm{L}$ in assay 2 (initial higher concentration of sugar cane molasses). 
The analysis of the primary effects (Fig. 1) indicated that the increase in sugar cane molasses concentration (from 10 to $50 \mathrm{~g} / \mathrm{L})$ positively influenced $(\mathrm{p}<0.05)$ the production of carotenoids $(615 \mu \mathrm{g} / \mathrm{L})$, biomass concentration $(5.1 \mathrm{~g} / \mathrm{L})$, total reducing sugar concentration in the culture $(4.3 \mathrm{~g} / \mathrm{L})$ and the initial C:N ratio (60) in the production medium. A different behaviour was observed with the increase of corn steep liquor concentration (from 3.5 to $9.5 \mathrm{~g} / \mathrm{L}$ ), which did not significantly influence response variables ( $p>0.05$ ), except the C:N ratio, which decreased to approx. 40 . Variations in the concentrations of sugar cane molasses and corn steep liquor in the studied range did not influence the carotenoid synthesis significantly ( $p>0.05$ ), which was confirmed by specific carotenoid mass fractions. The maximum of biomass and volumetric carotenoid concentrations was achieved in assays 2 (8.7 $\mathrm{g} / \mathrm{L}$ and $1040 \mu \mathrm{g} / \mathrm{L}$ respectively) and 4 (7.2 g/L and $1077 \mu \mathrm{g} / \mathrm{L}$ respectively) (Table 2 ). In general, the initial C:N ratio in the production medium above 40 increased the cell growth and volumetric concentration of carotenoids.

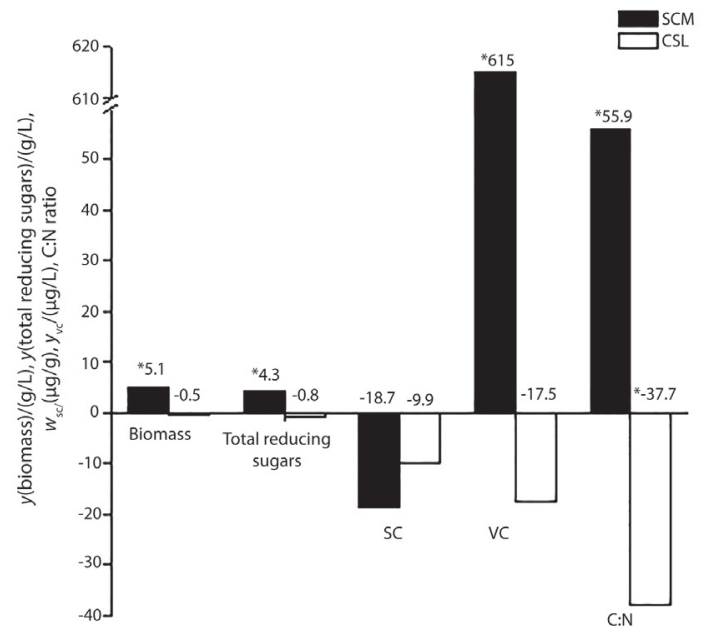

Fig. 1. Effects of the variables of sugar cane molasses (SCM) and corn steep liquor (CSL) on the responses of volumetric carotenoid (VC) concentration, specific carotenoid (SC) mass fraction, biomass concentration, total reducing sugars and $\mathrm{C}: \mathrm{N}$ ratio in the first central composite design (CCD). * ${ }^{\text {significantly different }(p<0.05)}$

The concentration of sugar cane molasses probably had a significant effect on the evaluated responses because its composition is considerably richer in carbohydrates than of corn steep liquor (Table 1). Carbon source is one of the most frequently studied variables because it influences the production of carotenoids, by affecting acetyl coenzyme A (CoA) synthesis, which converts to mevalonic acid, the first precursor of carotenoid production (20).

Thus, for the maximization of carotenoid production, a second CCD was conducted, where the concentration range of the sugar cane molasses was increased and that of the corn steep liquor decreased (Table 2). This experimental design demonstrated a variation in the responses, since the volumetric concentration of carotenoids varied from $623 \mu \mathrm{g} / \mathrm{L}$ (assay 1 ) to $1404 \mu \mathrm{g} / \mathrm{L}$ (assay 4), mass fraction of specific carotenoids from $127.71 \mu \mathrm{g} / \mathrm{g}$ (assay 1) to $173.39 \mu \mathrm{g} / \mathrm{g}$ (assay 4), biomass concentration from $4.88 \mathrm{~g} / \mathrm{L}$ (assay 1 ) to $8.10 \mathrm{~g} / \mathrm{L}$ (assay 4), C:N ratio from 109.26 (assay 3) to 435.75 (assay 2) and the final concentration of the total reducing sugars from 3.14 $\mathrm{g} / \mathrm{L}$ (assay 3) to $15.66 \mathrm{~g} / \mathrm{L}$ (assay 2).

The C:N ratio plays an important role in the synthesis of secondary metabolites (45). However, a lower concentration of nitrogen allows a higher $\mathrm{C}: \mathrm{N}$ ratio in the culture medium, which can affect the reduction in cell growth and the production of carotenoids $(31,44)$. The higher C:N ratio $(370.14$ and 435.75 in assays 1 and 2 in the second CCD; Table 2 ) negatively influenced cell growth and carotenoid production. Similar results were obtained by Saenge et al. (46), who studied different C:N ratios (140, 160 and 180) and found that the C:N ratio of 180 allowed higher carotenoid production, close to that obtained in this study (ratios 110-190 in assays 3 to 7 in the second CCD, Table 2).

A model fitting was accomplished in the second CCD (Table S1) with the independent variables (corn steep liquor and sugar cane molasses concentrations) and responses (biomass concentration, specific carotenoid mass fraction and volumetric carotenoid concentration).

On the basis of the ANOVA (Table S1), Eqs. 4, 5 and 6 were established resulting in first-order models to describe the volumetric carotenoid concentration in $\mu \mathrm{g} / \mathrm{L}$, specific carotenoid mass fraction in $\mu \mathrm{g} / \mathrm{g}$ and biomass concentration in $\mathrm{g} / \mathrm{L}$, respectively, as a function of corn steep liquor and sugar cane molasses concentrations:

$$
\begin{gathered}
\gamma_{\mathrm{vc}}=1067.7+151.50 \cdot \mathrm{X}_{1}+235.50 \cdot \mathrm{X}_{2} \\
w_{\mathrm{sc}}=154.85+18.75 \cdot \mathrm{X}_{2} \\
\gamma_{\text {biomass }}=6.38+0.7 \cdot \mathrm{X}_{1}+0.91 \cdot \mathrm{X}_{2}
\end{gathered}
$$

where $X_{1}$ is sugar cane molasses concentration in $g / L$, and $X_{2}$ is corn steep liquor concentration in $\mathrm{g} / \mathrm{L}$.

The pure error was low, indicating good reproducibility of the experimental data. Based on the F-test, the models are predictive, since the calculated F-value is higher than the critical F-value (3.4-, 2.48- and 2.91-fold for volumetric carotenoid, specific carotenoid mass fraction and biomass concentration, respectively), and the regression coefficients $(0.93,0.87$ and 0.96 for volumetric carotenoid concentration, specific carotenoid mass fraction and biomass concentration, respectively) are considered satisfactory (47). Coded models were used to generate contour curves (Fig. 2).

The maximization of the volumetric concentration of carotenoids (Fig. 2a) and biomass concentration (Fig. 2b) occurred with the increase in the concentration of corn steep liquor and sugar cane molasses. The maximum specific carotenoid mass fraction (Fig. $2 c$ ) was independent from the concentration range of the sugar cane molasses, but higher in concentrations of corn steep liquor.

These results are observable in assay 4 (second CCD, Table 2), which used the maximum levels (level+1) of the studied variables, verifying the highest volumetric carotenoid concentration of $1404 \mu \mathrm{g} / \mathrm{L}$, specific carotenoid mass fraction of $173.39 \mu \mathrm{g} / \mathrm{g}$, and biomass concentration of $8.1 \mathrm{~g} / \mathrm{L}$. 

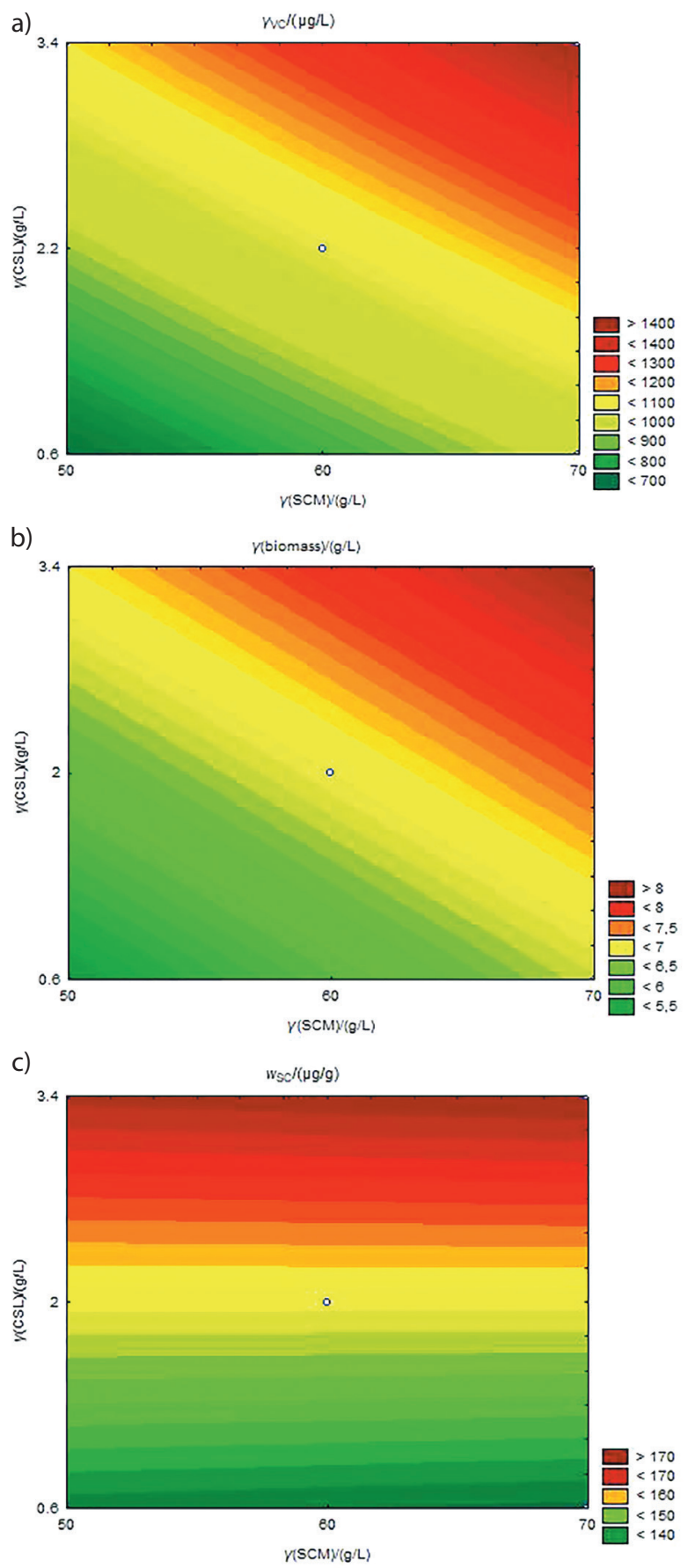

Fig. 2. Contour curves of: a) volumetric carotenoid concentration, b) biomass concentration obtained by CCD and c) specific carotenoid concentration as a function of the corn steep liquor (CSL) and sugar cane molasses (SCM) concentrations

\section{Validation of the model for the carotenoid bioproduction}

Fig. 3 shows the kinetics of the carotenoid production by Rhodotorula mucilaginosa. To find the highest volumetric concentration and specific mass fraction of carotenoids and biomass concentration, models generated by Eqs. 4, 5 and 6 were validated with the following composition of the production medium: $70 \mathrm{~g} / \mathrm{L}$ sugar cane molasses and $3.4 \mathrm{~g} / \mathrm{L}$ corn steep liquor (Fig. 3a). These assays demonstrated the expected behaviour in carotenoid bioproduction. The initial $\mathrm{pH}$ showed a small decrease in the first $24 \mathrm{~h}$, reaching at the end an average of 6.0. Culture medium had an initial C:N ratio of 143.65 , and the total reducing sugars decreased by an average of $50 \%$ in the first $96 \mathrm{~h}$, not being fully consumed at the end of the process ( $15 \mathrm{~g} / \mathrm{L}$ ). A maximum biomass concentration of $7.9 \mathrm{~g} / \mathrm{L}$ was achieved, approx. $2.5 \%$ less than the model (Eq. 6) had predicted ( $8.2 \mathrm{~g} / \mathrm{L}$ ). The volumetric carotenoid concentration reached a maximum of $1248.5 \mu \mathrm{g} / \mathrm{L}$ in 144 h, $14.2 \%$ less than predicted by Eq. 4 (1454.7 $\mu \mathrm{g} / \mathrm{L})$. Under the same conditions, the specific carotenoid mass fraction was $152.5 \mu \mathrm{g} / \mathrm{g}, 13.8 \%$ less than predicted by Eq. $5(173.6 \mu \mathrm{g} / \mathrm{g})$.

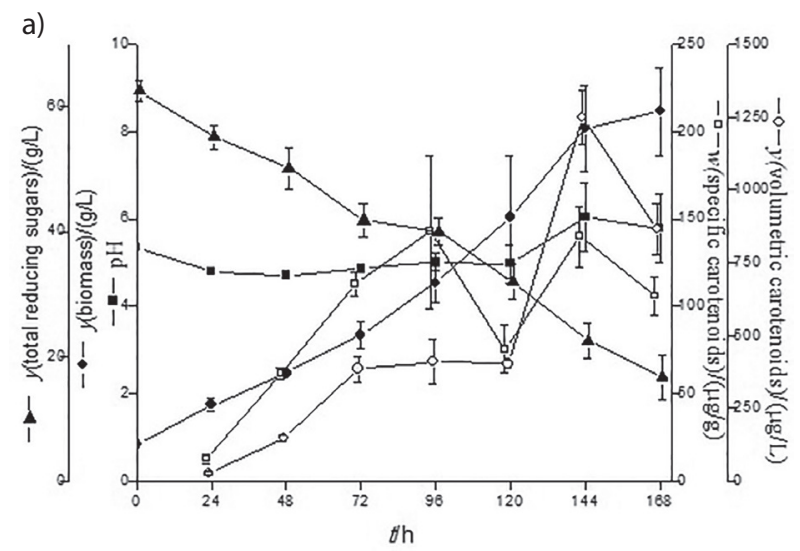

b)

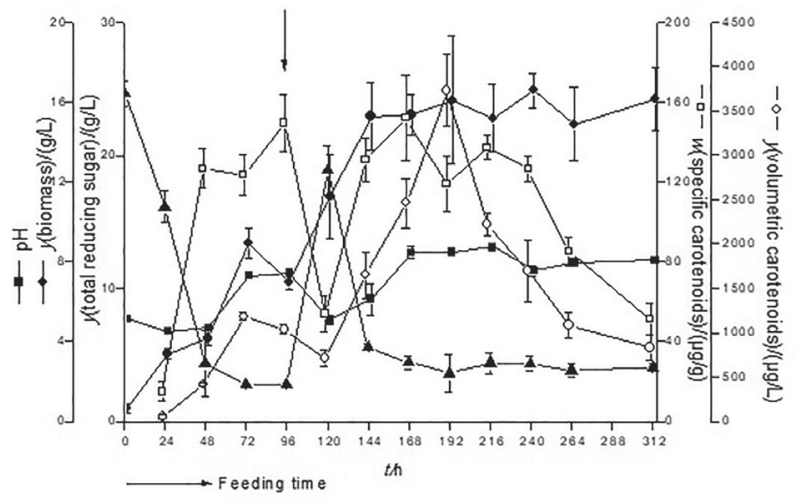

Fig. 3. Kinetics of the carotenoid production by Rhodotorula mucilaginosa at $25^{\circ} \mathrm{C}, 180 \mathrm{rpm}$ and an initial $\mathrm{pH}=6.0$ : a) $\gamma$ (sugar cane molasses) $=70 \mathrm{~g} / \mathrm{L}$ and $\gamma$ (corn steep liquor) $=3.4 \mathrm{~g} / \mathrm{L}$ used to validate the empirical models $(N=3)$, b) $\gamma$ (sugar cane molasses) $=30 \mathrm{~g} / \mathrm{L}$ and $\gamma$ (corn steep liquor) $=6.5 \mathrm{~g} / \mathrm{L}$ in a fed-batch fermentation at feeding time $t=96 \mathrm{~h}$

The relative deviations obtained during the experimental validation were less than $20 \%$ from those predicted by the models. Therefore, the experimental results fit well with the proposed models (40). The models generated for the other responses in this study were not predictive.

The agroindustrial medium used by $R$. mucilaginosa in this study was $70 \mathrm{~g} / \mathrm{L}$ sugar cane molasses and $3.4 \mathrm{~g} / \mathrm{L}$ corn steep liquor, with a C:N ratio of approx. 140, reaching a maximum of total carotenoid production $1248.5 \mu \mathrm{g} / \mathrm{L}(152.5 \mu \mathrm{g} / \mathrm{g})$ and 
biomass concentration $7.9 \mathrm{~g} / \mathrm{L}$, at $25^{\circ} \mathrm{C}$ and $180 \mathrm{rpm}$ with initial $\mathrm{pH}=6.0$ in $144 \mathrm{~h}$. Under these conditions similar results to those on standard YM medium $(1200 \mu \mathrm{g} / \mathrm{L}$, Table 1) were achieved, using only two agroindustrial byproducts. In addition, a $270 \%$ increase in the production of the volumetric carotenoid concentration and $75 \%$ in the biomass production was achieved compared to the initial agroindustrial medium with initial C:N ratio 6.0 (36.5 g/L corn steep liquor with 6.0 $\mathrm{g} / \mathrm{L}$ sugar cane molasses, Table 1 ).

The increase in the volumetric concentration of carotenoids achieved in this study through experimental design was at least 3 and 5 times higher than that reached by Otero (25) and Cipolatti (26), respectively, with the same yeast strain and similar agroindustrial substrates in other concentrations.

\section{Carotenoid production in the fed-batch fermentation}

Two culture media were selected for the study of the fed-batch fermentation. One was the previously optimized medium (3.4 g/L corn steep liquor with $70 \mathrm{~g} / \mathrm{L}$ sugar cane molasses), and the second culture medium $(6.5 \mathrm{~g} / \mathrm{L}$ corn steep liquor with $30 \mathrm{~g} / \mathrm{L}$ sugar cane molasses) in batch process reached approx. $60 \%$ of the optimum carotenoid production (run 5 to run 7 in the first central composite design in Table 2). Additionally, in this process a depletion of total reducing sugars occurred in $96 \mathrm{~h}$ (data not shown), making it interesting for fed-batch production with the pulse feeding with $25 \mathrm{~mL}$ of medium (32). The biomass concentration increased approx. by $70 \%$ (run 1 to 2 ) and $168 \%$ (run 3 to 4 ) in the fed-batch batch compared to the batch process (Table 3) in both media.

During the follow-up of the carotenoid production in fed-batch fermentation with feeding in $96 \mathrm{~h}$ (Fig. 3b), the $\mathrm{pH}$ decreased during the first $24 \mathrm{~h}$ of culture after a gradual increase. With feeding, the $\mathrm{pH}$ dropped again in the first hours and gradually increased throughout the process. This $\mathrm{pH}$ change was also observed by Cipolatti (26). The decline in the $\mathrm{pH}$ probably occurs as a consequence of cell development and the release of compounds, such as acetic acid, alcohol or citric acid cycle intermediates during the adaptation phase (24).

The synthesis of the carotenoids was not significantly influenced $(p>0.05$ ) by the fed-batch process or the composition of the culture medium, since there was no variation in the mass fraction of specific carotenoids. Similar was observed for the volumetric carotenoid concentration, where a significant increase $(\mathrm{p}<0.05)$ was observed during fed-batch production by $78 \%$ (trials 1 to 2 in Table 3 ) and $400 \%$ (trials 3 to 4 in Table 3). Therefore, the production medium containing $6.5 \mathrm{~g} / \mathrm{L}$ corn steep liquor with $30 \mathrm{~g} / \mathrm{L}$ sugar cane molasses (run 4 in Table 3) was the best for carotenoid and biomass production in the fed-batch process with different feeding strategies (Fig. 4).

There was an increase ( $p>0.05$ ) of about $150 \%$ in biomass accumulation in all feeding strategies on medium containing $6.5 \mathrm{~g} / \mathrm{L}$ corn steep liquor with $30 \mathrm{~g} / \mathrm{L}$ sugar cane molasses, when compared to that of the batch fermentation (Fig. 4a). However, it was observed that there was no significant difference $(p<0.05)$ in the carotenoid synthesis between the evaluated strategies (Fig. 4c). The highest volumetric carotenoid concentration was in run 3 with the feeding pulse in 96 h of culture $(3726.7 \mu \mathrm{g} / \mathrm{L})$, when a significant increase $(p<0.05)$ compared to the other feeding strategies and from the batch process was observed (Fig. 4b). In relation to the YM standard medium (Table 1), there was a 3 -fold increase in carotenoid production $(1200 \mu \mathrm{g} / \mathrm{L})$. The volumetric productivity reached $19.40 \mu \mathrm{g} /(\mathrm{L} \cdot \mathrm{h})$ in run 3 , which was significantly $(\mathrm{p}<0.05)$ higher than under other conditions. The biomass productivity varied from 0.05 to $0.1 \mathrm{~g} /(\mathrm{L} \cdot \mathrm{h})$, depending on feeding strategy. Colet et al. (48) obtained biomass productivity between 0.05 and $0.085 \mathrm{~g} /(\mathrm{L} \cdot \mathrm{h})$, which was similar to the results of this study.

Colet et al. (48) evaluated the production of carotenoids in fed-batch fermentation by Sporidiobolus salmonicolor in a bioreactor with $1 \mathrm{~L}$ working volume. The composition of the medium was: peptone $15 \mathrm{~g} / \mathrm{L}$, malt extract $5 \mathrm{~g} / \mathrm{L}$ and glycerol $80 \mathrm{~g} / \mathrm{L}$. The maximum total carotenoid concentration obtained in their studies was $4400 \mu \mathrm{g} / \mathrm{L}$ in $96 \mathrm{~h}$ with a $112.5 \mathrm{~mL}$ feed every $12 \mathrm{~h}$ (Table 4 (18,48-50)). Dias et al. (51) studied the production of lipids and carotenoids by Rhodosporidium toruloides in a batch and fed-batch fermentation in a bench bioreactor with $5 \mathrm{~L}$ working volume. The maximum production obtained was $33.4 \mathrm{mg} / \mathrm{L}$ under conditions of initial $\mathrm{pH}=5$, temperature $30^{\circ} \mathrm{C}$ with strategy of one pulse feeding at the end of the batch culture in the medium containing $9 \mathrm{~g} / \mathrm{L} \mathrm{Mg-}$ $\mathrm{SO}_{4} \cdot 7 \mathrm{H}_{2} \mathrm{O}, 20 \mathrm{~g} / \mathrm{L}$ yeast extract and $60 \mathrm{~g} / \mathrm{L}$ glucose.

Table 4 summarizes the carotenoid production findings in the literature and compares them with the results obtained in this work. The study demonstrated promising results considering that the medium contains only two agroindustrial byproducts, sugar cane molasses and corn steep liquor, and was conducted in shake flasks.

Table 3. Biomass concentration and carotenoid production on agroindustrial media in batch and fed-batch fermentation with different feeding strategies

\begin{tabular}{cccccccc} 
Trial & $\gamma($ medium $) /(\mathrm{g} / \mathrm{L})$ & Process & Feeding pulse & $\gamma($ biomass $) /(\mathrm{g} / \mathrm{L})$ & $w_{\mathrm{sc}} /(\mu \mathrm{gg} / \mathrm{g})$ & $\gamma_{\mathrm{vc}} /(\mu \mathrm{gg} / \mathrm{L})$ & $t_{\mathrm{c}} / \mathrm{h}$ \\
1 & & Batch & - & $(7.9 \pm 0.9)^{\mathrm{b}}$ & $(152 \pm 13)^{\mathrm{a}}$ & $(1248 \pm 94)^{\mathrm{c}}$ & 144 \\
2 & CSL 3.4+SCM 70 & Fed-batch $t=168 \mathrm{~h}$ & 50 & $(13.7 \pm 1.2)^{\mathrm{a}}$ & $(139 \pm 22)^{\mathrm{a}}$ & $(2229 \pm 1534)^{\mathrm{b}}$ & 192 \\
3 & & Batch & - & $(6.0 \pm 0.8)^{\mathrm{b}}$ & $(123 \pm 9)^{\mathrm{a}}$ & $(740 \pm 55)^{\mathrm{d}}$ & 144 \\
4 & CSL 6.5+SCM 30 & Fed-batch $t=96 \mathrm{~h}$ & 25 & $(16.1 \pm 4.5)^{\mathrm{a}}$ & $(118.8 \pm 13.7)^{\mathrm{a}}$ & $(3726.7 \pm 506.0)^{\mathrm{a}}$ & 192 \\
\hline
\end{tabular}

$\mathrm{CSL}=$ corn steep liquor, $\mathrm{SCM}=$ sugar cane molasses; $w_{\mathrm{sc}}=$ specific mass fraction of carotenoids, $\gamma_{v c}=$ volumetric concentration of carotenoids, $t_{c}=$ time of cultivation; different letters in the same column indicate a significant difference $(p<0.05)$ according to Tukey's test 
Table 4. Carotenoid production obtained by cultivation of red yeasts on different substrates and operating conditions

\begin{tabular}{|c|c|c|c|c|c|}
\hline Strain & Substrate & Operating conditions & $\begin{array}{l}\text { Cultivation } \\
\text { method }\end{array}$ & $\gamma_{\mathrm{v} c} /(\mu \mathrm{g} / \mathrm{L})$ & Reference \\
\hline Rhodotorula mucilaginosa & Sugar cane molasses & $\begin{array}{c}\text { Incubated in a shake flask at } 25^{\circ} \mathrm{C} \text {, } \\
180 \mathrm{rpm} \text { and initial } \mathrm{pH}=6.0\end{array}$ & Batch & 1248.5 & This work \\
\hline Rhodotorula mucilaginosa & Sugar cane molasses & $\begin{array}{c}\text { Incubated in a shake flask at } 25^{\circ} \mathrm{C} \text {, } \\
180 \mathrm{rpm} \text { and initial } \mathrm{pH}=6.0\end{array}$ & Fed-batch & 3726.0 & This work \\
\hline Sporidiobolus salmonicolor & $\begin{array}{c}\text { Crude glycerol, maceration } \\
\text { water and rice parboiling water }\end{array}$ & $\begin{array}{l}\text { Stirred tank bioreactor at } 25^{\circ} \mathrm{C} \text {, } \\
\text { initial } \mathrm{pH}=4.0 \text { and } 180 \mathrm{rpm}\end{array}$ & Batch & 7388.0 & $(49)$ \\
\hline Rhodotorula glutinis & Wastewater food industry & $\begin{array}{l}\text { Incubated in a shake flask at } 25 \\
{ }^{\circ} \mathrm{C}, 115 \mathrm{rpm} \text { and initial } \mathrm{pH}=5.5\end{array}$ & Batch & 1200.0 & $(50)$ \\
\hline Sporidiobolus pararoseus & Sugar cane molasses & $\begin{array}{l}\text { Stirred tank bioreactor at } 25^{\circ} \mathrm{C} \text {, } \\
\text { initial } \mathrm{pH}=6.0 \text {, and } 158 \mathrm{rpm}\end{array}$ & Batch & 1969.3 & (18) \\
\hline Sporidiobolus pararoseus & Sugar cane molasses & $\begin{array}{c}\text { Incubated in a shake flask at } 27.5^{\circ} \mathrm{C} \text {, } \\
150 \mathrm{rpm} \text { and initial } \mathrm{pH}=4.0\end{array}$ & Batch & 565.0 & $(18)$ \\
\hline Sporidiobolus salmonicolor & Glycerol & $\begin{array}{c}\text { Stirred tank bioreactor at } 25^{\circ} \mathrm{C}, 180 \\
\text { rpm and initial } \mathrm{pH}=4.0\end{array}$ & Fed-batch & 4400.0 & (48) \\
\hline
\end{tabular}

a)

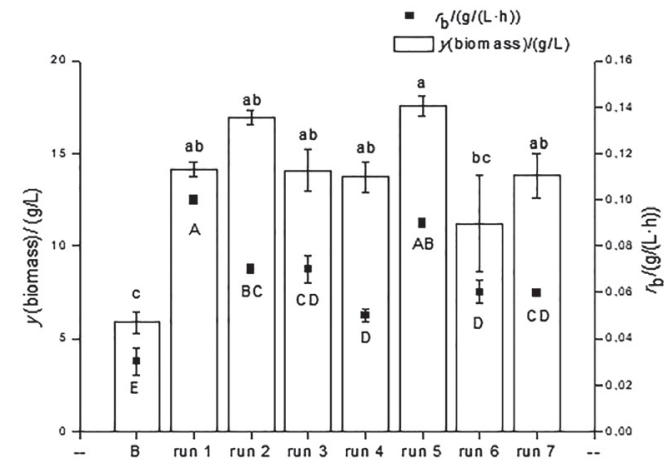

b)

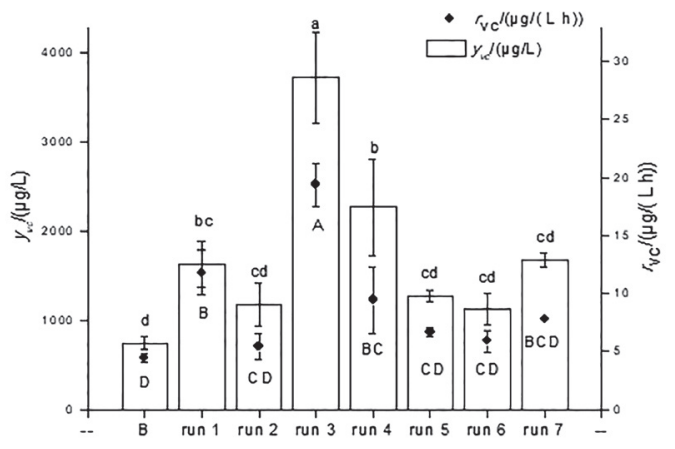

c)

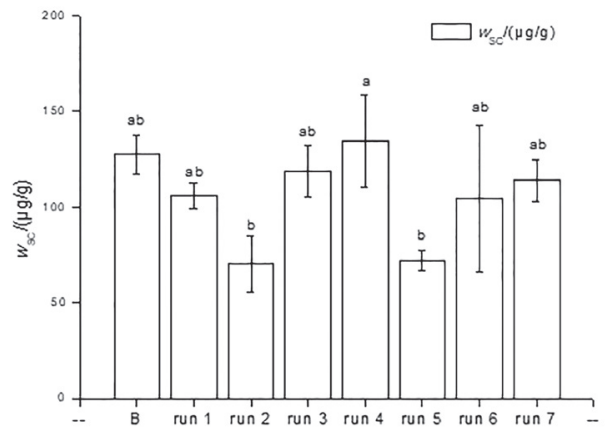

Fig. 4. Comparison of: a) biomass concentration in batch and fed-batch fermentations with $6.5 \mathrm{~g} / \mathrm{L}$ corn steep liquor and $30 \mathrm{~g} / \mathrm{L}$ sugar cane molasses medium, b) volumetric concentration of carotenoids and c) specific carotenoid mass fraction. $B=$ batch process, fed-batch run $(t / h)$ : 1) 48 , 2) 72, 3) 96, 4) 48 and 96, 5) 72 and 120, 6) 96 and 144, 7) 96 and 168 . The results are expressed as mean values \pm standard deviations $(N=3)$; different letters (lowercase for biomass and volumetric carotenoid concentrations and uppercase for biomass and volumetric carotenoid productivity) indicate a significant difference $(p<0.05)$ according to Tukey's test

\section{CONCLUSIONS}

In this study, it was possible to use agroindustrial byproducts (sugar cane molasses, corn steep liquor and raw glycerol) to produce carotenoids by Rhodotorula mucilaginosa. The carotenoid production in the batch fermentation in the medium containing $70 \mathrm{~g} / \mathrm{L}$ sugar cane molasses and $3.4 \mathrm{~g} / \mathrm{L}$ corn steep liquor reached a maximum of $1248.5 \mu \mathrm{g} / \mathrm{L}(152.5 \mu \mathrm{g} / \mathrm{g})$, with $7.9 \mathrm{~g} / \mathrm{L}$ biomass concentration. The fed-batch fermentation using the agroindustrial culture medium (6.5 g/L corn steep liquor with 30 $\mathrm{g} / \mathrm{L}$ sugar cane molasses) with a 96-hour feed gave promising results of $3726.7 \mu \mathrm{g} / \mathrm{L}$ carotenoids $(118.8 \mu \mathrm{g} / \mathrm{g})$. Therefore, this demonstrates the potential of using agroindustrial byproducts as an alternative source of nutrients in the batch and fed-batch fermentation. In summary, our study demonstrated the feasibility of minimizing costs of the production medium, adding value to these byproducts, and possibly decreasing the generation of waste from industrial processes and reducing their environmental impact.

\section{ACKNOWLEDGEMENTS}

The authors are grateful for FAPERGS (Foundation Research Support in the state of Rio Grande do Sul), CNPq (National Council of Science and Technological Development) and the support of the Support Program for Academic Production Publication (Programa de Apoio à Publicação da Produção Acadêmica)/PROPESP/FURG/2018. This study was financed in part by the Coordination of Superior Level Staff Improvement (CAPES) Brasil, Finance Code 001.

\section{SUPPLEMENTARY MATERIAL}

All supplementary material is availabe at www.ftb.com.hr.

\section{ORCID IDs}

T.V.D. Rodrigues (1) https://orcid.org/0000-0002-2482-5758

T.D. Amore 이 https://orcid.org/0000-0002-2260-4118

E.C. Teixeira (1) https://orcid.org/0000-0002-7381-1467

J.F.M. Burkert ํ https://orcid.org/0000-0002-8504-5376 


\section{REFERENCES}

1. Kirti K, Amita S, Priti S, Kumar AM, Jyoti S. Colorful world of microbes: Carotenoids and their applications. Adv Biol. 2014;2014:Article ID 837891.

https://doi.org/10.1155/2014/837891

2. Damodaran S, Parkin KL, Fennema OR, editors. Fennema's Food Chemistry. Boca Raton, FL, USA: CRS Press; 2010 (in Spanish).

3. Rodriguez-Amaya DB. Update on natural food pigments - A mini-review on carotenoids, anthocyanins, and betalains. Food Res Int. 2019;124:200-5.

https://doi.org/10.1016/j.foodres.2018.05.028.

4. Report FOD025E. The global market for carotenoids. Wellesley, MA, USA: BCC Research, LLC; 2018. Available from: https://www.bccresearch.com/market-research/food-andbeverage/the-global-market-for-carotenoids.html.

5. Neves MIL, Silva EK, Meireles MAA. Trends and challenges in the industrialization of natural colorants. Food and Public Health. 2019;9(2):33-44.

https://doi.org/10.5923/j.fph.20190902.01

6. Jomova K, Valko M. Health protective effects of carotenoids and their interactions with other biological antioxidants. Eur J Med Chem. 2013;70:102-10.

https://doi.org/10.1016/j.ejmech.2013.09.054

7. Sahin K, Akdemir F, Orhan C, Tuzcu M, Gencoglu H, Sahin $\mathrm{N}$, et al. (3R, $\left.3^{\prime} \mathrm{R}\right)$-zeaxanthin protects the retina from photo-oxidative damage via modulating the inflammation and visual health molecular markers. Cutan Ocul Toxicol. 2019;38(2):161-8.

https://doi.org/10.1080/15569527.2018.1554667

8. Wolak T, Paran E. Can carotenoids att enuate vascular aging? Vasc Pharmacol. 2013;59(3-4):63-6.

https://doi.org/10.1016/j.vph.2013.07.006

9. Ambati RR, Gogisetty D, Aswathanarayana RG, Ravi S, Bikkina PN, Bo L, Yuepeng S. Industrial potential of carotenoid pigments from microalgae: Current trends and future prospects. Crit Rev Food Sci. 2019;59(12):1880-902.

https://doi.org/10.1080/10408398.2018.1432561

10. Di Lena G, Casini I, Lucarini M, Lombardi-Boccia G. Carotenoid profiling of five microalgae species from large-scale production. Food Res Int. 2019;120:810-18.

https://doi.org/10.1016/j.foodres.2018.11.043

11. Santos Ribeiro JE, Martini M, Altomonte I, Salari F, Nardoni $\mathrm{S}$, Sorce C, et al. Production of Chorella protothecoides biomass, chorophyll and carotenoids using the dairy industry by-product scotta as a subtrate. Biocatal Agric Biotechnol. 2017;11:207-13.

https://doi.org/10.1016/j.bcab.2017.07.007

12. Heider SAE, Peters-Wendisch P, Netzer R, Stafnes M, Brautaset $T$, Wendisch VF. Production and glucosylation of $C_{50}$ and $C_{40}$ carotenoids by metabolically engineered
Corynebacterium glutamicum. Appl Microbiol Biotechnol. 2014;98(3):1223-35.

https://doi.org/10.1007/s00253-013-5359-y

13. Squillaci G, Parrella R, Carbone V, Minasi P, La Cara F, Morana A. Carotenoids from the extreme halophilic archaeon Haloterrigena turkmenica: Identification and antioxidant activity. Extremophiles. 2017;21(5):933-45.

https://doi.org/10.1007/s00792-017-0954-y

14. Oren A, Hirschberg J, Mann V, Jehlička J. Effects of nicotine on the biosynthesis of carotenoids in halophilic Archaea (class Halobacteria): An HPLC and Raman spectroscopy study. Extremophiles. 2018;22(3):359-66.

https://doi.org/10.1007/s00792-018-0995-x

15. Castrillo M, Luque EM, Pardo-Medina J, Limón MC, Corrochano LM, Avalos J. Transcriptional basis of enhanced photoinduction of carotenoid biosynthesis at low temperature in the fungus Neurospora crassa. Res Microbiol. 2018;169(2):78-89.

https://doi.org/10.1016/j.resmic.2017.11.003

16. Pandey N, Jain R, Pandey A, Tamta S. Optimisation aand characterisation of the orange pigment produced by a cold adapted strain of Penicillium sp. (GBPI_P155) isolated from mountain ecosystem. Mycology. 2018;9(2):81-92.

https://doi.org/10.1080/21501203.2017.1423127

17. Moroni Silva C, de Matos de Borba T, Kalil SJ, Burkert JFM. Raw glycerol and parboiled rice effluent for carotenoid production: Effect of the composition of culture medium and initial pH. Food Technol Biotechnol. 2016;54(4):489-96.

https://doi.org/10.17113/ftb.54.04.16.4410

18. Molins Borba C, das Neves Tavares M, Costa Moraes C, Fernandes de Medeiros Burkert J. Carotenoid production by Sporidiobolus pararoseus in agroindustrial medium: Optimization of culture conditions in shake flasks and scale-up in a stirred tank fermenter. Braz J Chem Eng. 2018;35(2):509-20. https://doi.org/10.1590/0104-6632.20180352s20160545

19. Valduga E, Rausch Ribeiro AH, Cence K, Colet R, Tiggemann L, Zeni J, Toniazzo G. Carotenoides production from a newly isolated Sporidiobolus pararoseus strain using agroindustrial subtrates. Biocatal Agric Biotechnol. 2014;3(2):207-13. https://doi.org/10.1016/j.bcab.2013.10.001

20. Mata-Gómez LC, Montañez JC, Méndez-Zavala A, Aguilar CN. Biotechnological production of carotenoids by yeasts: An overview. Microb Cell Fact. 2014;13Article No. 12. https://doi.org/10.1186/1475-2859-13-12

21. Cheng YT, Yang CF. Using strain Rhodotorula mucilaginosa to produce carotenoids using food wastes. J Taiwan Inst Chem Eng. 2016;61:270-5.

https://doi.org/10.1016/j.jtice.2015.12.027

22. Kot AM, Błażejak S, Kurcz A, Bryś J, Gientka I, Bzducha-Wróbel $A$, et al. Effect of initial $\mathrm{pH}$ of medium with potato wastewater and glycerol on protein, lipid and carotenoid biosynthesis by Rhodotorula glutinis yeast. Electron J Biotechnol. 2017;27:25-31.

https://doi.org/10.1016/j.ejbt.2017.01.007 
23. Petrik S, Obruča S, Benešová P, Márová I. Bioconversion of spent coffee grouns into carotenoids and other valuable metabolites by selected red yeast strains. Biochem Eng J. 2014;90:307-15.

https://doi.org/10.1016/j.bej.2014.06.025

24. Valduga E, Oliveira Tatsch $P$, Tiggemann L, Treichel H, Toniazzo G, Zeni J, et al. Carotenoids production: Microorganisms as source of natural dyes. Quím Nova. 2009;32(9):2429-36 (in Portuguese).

https://doi.org/10.1590/S0100-40422009000900036

25. Otero DM. Bioprospecting of wild yeasts for producing carotenoids [MSc Thesis]. Rio Grande, Rio Grande do Sul, Brazil: Federal University of Rio Grande; 2011 (in Portuguese).

26. Cipolatti EP. Obtaining microbial carotenoids with antioxidant activity from agroindustrial co-products [MSc Thesis]. Rio Grande, Rio Grande do Sul, Brazil: Federal University of Rio Grande; 2012 (in Portuguese).

27. Schmidell W, Lima UA, Aquarone E, Borzani W, editors. Industrial biotechnology. São Paulo, Brazil: Edgard Blücher; 2001 (in Portuguese).

28. Luna-Flores $\mathrm{CH}$, Ramírez-Cordova JJ, Pelayo-Ortiz C, Femat R, Herrera-López EJ. Batch and fed-batch modeling of carotenoids production by Xanthophyllomyces dendrorhous using Yucca fillifera date juice as substrate. Biochem Eng J. 2010;53(1):131-6.

https://doi.org/10.1016/j.bej.2010.10.004

29. Parajó JC, Santos VS, Vázquez M. Optimization of carotenoid production by Phaffia rhodozyma cell grown on xylose. Process Biochem. 1998;33(2):181-7.

https://doi.org/10.1016/S0032-9592(97)00045-9

30. Michelon M, de Matos de Borba T, da Silva Rafael R, Veiga Burkert CA, Fernandes de Medeiros Burkert J. Extration of carotenoids from Phaffia rhodozyma: A comparison between different techniques of cell disruption. Food Sci Biotechnol. 2012;21(1):1-8.

https://doi.org/10.1007/s10068-012-0001-9

31. Alves da Silva Rios D, de Matos de Borba T, Juliano Kalil S, Fernandes de Medeiros Burkert J. Rice parboiling wastewater in maximization of carotenoids bioproduction by Phaffia rhodozyma. Ciênc Agrotec. 2015;39(4):401-10.

https://doi.org/10.1590/S1413-70542015000400011

32. Chang YH, Chang KS, Hsu CL, Chuang LT, Chen CY, Huang FY, Jang HD. A comparative study on batch and fed-batch cultures of oleaginous yeast Cryptococcus sp. in glucose-based media and corncob hydrolysate for microbial oil production. Fuel. 2013;105:711-7.

https://doi.org/10.1016/j.fuel.2012.10.033

33. Dos Santos da Fonseca RA, da Silva Rafael R, Juliano Kalil $S$, Veiga Burkert CA, Fernandes de Medeiros Burkert J. Different cell disruption methods for astaxanthin recovery by Phaffia rhodozyma. Afr J Biotechnol. 2011;10(7):1165-71.

https://doi.org/10.5897/AJB10.1034
34. Goodwin TW, editor. Chemistry and biochemistry of plant pigments. London, UK: Academic Press; 1976.

35. AOAC Official Method 972.44. Microbiological method. Rockville, MD, USA: AOAC International; 2000.

36. Choi MH, Park YH. Production of yeast biomass using waste Chinese cabbage. Biomass Bioenerg. 2003;25(2):221-6. https://doi.org 10.1016/S0961-9534(02)00194-0

37. Miller GL. Use of dinitrosalicylic acid reagent for determination of reducing sugar. Anal Chem. 1959;31(3):426-8. https://doi.org/10.1021/ac60147a030

38. Maldonade IR, Carvalho PGB, Ferreira NA. Technical communiqué 85 : Protocol for the determination of total sugars in vegetables by the DNS method. Brasília: Embrapa Hortaliça; 2013 (in Portuguese).

39. Box GEP, Hunter WG, Hunter JS, editors. Statistics for experimenters: An introduction to design, data analysis, and model building. New York, NY, USA: John Wiley \& Sons; 1978.

40. Rodrigues MI, lemma AF. Experimental design and process optimization. Boca Raton, FL, USA: CRC Press; 2014.

41. Silva CM, Borba TM, Burkert CAV, Burkert JFM. Carotenoid production by Phaffia rhodozyma using raw glycerol as an additional carbon source. Int J Food Eng. 2012;8(4):Article No. 18. https://doi.org 10.1515/1556-3758.2843

42. Centeno da Rosa CF, Michelon M, Burkert JFM, Kalil SJ, Burkert CAV. Effect of medium composite on changes of surface tension during cultivation of Pseudomonas aeruginosa LBM10 growing on glycerol. J Eng Res Appl. 2015;5(4):41-6.

43. Ribeiro VA, Burkert CAV. Exopolysaccharides produced by Rhizobium: Production, composition and rheological properties. J Polym Biopolymer Phys Chem. 2016;4(1):1-6.

https://doi.org10.12691/jpbpc-4-1-1

44. Vustin MM, Belykh EN, Kishilova SA. Relationship between astaxanthin production and intensity of anabolic processes in the yeast Phaffia rhodozyma. Microbiology. 2004;73(6):643-9.

https://doi.org/10.1007/s11021-005-0004-0

45. Garbayo I, Vilchez C, Nava-Saucedo JE, Barbotin JN. Nitrogen, carbon and light-mediated regulation studies of carotenoid biosynthesis in immobilized mycelia of Gibberella fujikuroi. Enzyme Microb Technol. 2003;33(5)629-34.

https://doi.org/10.1016/S0141-0229(03)00182-0

46. Saenge C, Cheirsilp B, Suksaroge TT, Bourtoom T. Potential use of oleaginous red yeast Rhodotorula glutinis for the bioconversion of crude glycerol from biodiesel plant to lipids and carotenoids. Process Biochem. 2011;46(1):210-8.

https://doi.org/10.1016/j.procbio.2010.08.009

47. Haaland PD, editor. Experimental design in biotechnology. New York, NY, USA: Marcel Dekker; 1989.

48. Colet R, Di Luccio M, Valduga E. Fed-batch production of carotenoids by Sporidiobolus salmonicolor (CBS 2636): Kinetic and stoichiometric parameters. Eur Food Res Technol. 2015;240(1):173-82.

https://doi.org/10.1007/s00217-014-2318-5 
49. Colet R, Urnau L, Bampi J, Zeni J, Bernar Dias B, Rodrigues E, et al. Use of low-cost agro products as substrate in semi-continuous process to obtain carotenoids by Sporidiobolus salmonicolor. Biocatal Agric Biotechnol. 2017;11:268-74. https://doi.org/10.1016/j.bcab.2017.07.015

50. Schneider T, Graeff-Hönninger S, French WT, Hernandez R, Merkt N, Claupein W, et al. Lipid and carotenoid production by oleaginous red yeast Rhodotorula glutinis cultivated on brewery effluents. Energy. 2013;61:34-43.

https://doi.org/10.1016/j.energy.2012.12.026

51. Dias C, Sousa S, Caldeira J, Reis A, Lopes da Silva T. New dual-stage $\mathrm{pH}$ control fed-batch cultivation strategy for the improvement of lipids and carotenoids production by the red yeast Rhodosporidium toruloides NCYC921. Bioresour Technol. 2015;189:309-18.

https://doi.org/10.1016/j.biortech.2015.04.009 